JEMAP: Jurnal Ekonomi, Manajemen, Akuntansi, dan Perpajakan

ISSN: 2622-612X (Media Online) | Vol.3 | No.2 | Oktober 2020

\title{
PENGARUH VANITY SEEKING, PURCHASE EXPERIENCE, DAN CELEBRITY ENDORSER, PADA MINAT BELI ULANG DENGAN SIKAP TERHADAP LANEIGE SEBAGAI VARIABEL MEDIASI
}

\author{
Povy Amelia', Herry Maridjo \\ herrym@usd.ac.id \\ Magister Manajemen Universitas Sanata Dharma Yogyakarta
}

\begin{abstract}
This research aims to determine: the influence of vanity seeking on repurchase intention with attitude toward laneige as a mediating variable; the influence of purchasing experience on repurchase intention with attitude towards laneige as a mediating variable; and the influence of celebrity endorser on repurchase intention with attitude toward laneige as a mediating variable. The population in this research is Laneige consumers who have already bought Laneige with a total sample of 96 respondents. The sampling technique used is convenience sampling. The sampling technique used is convenience sampling. The validity test uses the construct validity test of convergent and discriminant constructs, and reliability test uses the formula of composite reliability and Cronchbach's alpha. The data analysis technique used in this research is SEM using Partial Least Squares (SEM-PLS). The results showed that Vanity seeking did not have a positive influence on repurchase intention with attitudes toward Laneige as a mediating variable. Purchase experience had a positive influence on repurchase intention with partial mediation by attitudes towards Laneige. Celebrity endorser had positive influence on repurchase intention with full mediation by the attitude towards Laneige.
\end{abstract}

Keywords: vanity seeking, purchase experience, celebrity endorser, repurchase intention, attitude

\section{LATAR BELAKANG}

Berkulit putih bersih masih menjadi ukuran kecantikan bagi wanita Indonsia. Kecantikan wanita Indonesia banyak dipengaruhi oleh Korean wave (gelombang hallyu). Pengemar Hallyu di dunia telah mencapai hampir 90 juta orang per akhir tahun 2018 dengan Asia sebagai base terbesar (CNN Indonesia). Drama Korea dan K-POP (Korean Pop) adalah gerbang utama Korean wave memasuki Indonesia. Banyak orangorang Indonesia terutama wanita ingin tampil seperti salah satu public figure Korea 
JEMAP: Jurnal Ekonomi, Manajemen, Akuntansi, dan Perpajakan

yang mereka gemari. Mereka mengikuti tren K-Beauty dengan tujuan untuk memperoleh kulit putih yang sehat seperti idolanya. Fenomena ini memberikan banyak peluang bagi merek-merek kecantikan asal Korea yang masuk ke Indonesia salah satunya adalah Laneige.

Laneige sangat menarik untuk diteliti karena survei menunjukkan $7,7 \%$ segmen produk kecantikan Indonesia berhasil dikuasai Laneige (http://marketeers.com) dibanding dengan pesaingnya Insfree yang hanya menguasi 4,6\% segmen kecantikan Indonesia, selain itu terdapat sebuah komunitas pengguna setia Laneige di Indonesia yaitu Sparkling Squad, hal ini menunjukkan bahwa terhadap produk kecantikan asal Korea Selatan wanita Indonesia terbanyak memiliki sikap positif terhadap merek Laneige dan memilih untuk membelinya. Fakta ini menimbulkan pertanyaan apa yang menyebabkan konsumen lebih memilih menggunakan Laneige dibanding dengan merek produk kecantikan asal Korea lainnya. Dari berbagai kajian literatur, peneliti menemukan bahwa ada beberapa hal yang dapat mempengaruhi sikap positif dan minat beli ulang konsumen terhadap suatu produk yaitu vanity seeking, purchase experience, dan celebrity endorser.

Setiap konsumen memiliki karakteristik kepribadian yang dapat mempengaruhi keputusan pembelian. Karakteristik konsumen dapat digunakan sebagai salah satu dasar pembuatan keputusan pemasaran karena konsumen memilih produk yang sesuai dengan kepribadiannya (Hawkins \& Mothersbaugh, 2016). Vanity seeking adalah salah satu karakteristik konsumen yang dapat mempengaruhi keputusan pembelian konsumen. Menurut Durvasula, Lysonski, \& Watson (dalam Ahmed, Faroq, Zakaria, Iqbal \& Ali, 2014), vanity adalah peningkatan diri pada manusia yang dipengaruhi oleh masyarakat dan juga diturunkan oleh masyarakat. Dewasa ini orang-orang cenderung berusaha membuktikan diri kepada orang lain dengan berbagai cara antara lain dari segi fisik dan prestasi. Melihat tren tersebut hampir semua pemasar mempromosikan produk dengan klaim bisa meningkatkan penampilan, atau meningkatkan prestasi seseorang.

Menurut Arnold, Price, \& Zinkhan (2002), pengalaman berbelanja adalah hal 
JEMAP: Jurnal Ekonomi, Manajemen, Akuntansi, dan Perpajakan

yang sangat penting dalam perilaku konsumen. Pengalaman berbelanja yang dimiliki oleh konsumen memiliki dampak penting pada apa yang dipelajari dan diingat oleh konsumen. Pengalaman belanja konsumen sebelumnya memengaruhi perilaku belanja mereka di masa depan (Eastlick, 1996, Eastlick \& Lotz, 1999, dalam Kaushik \& Singh, 2013).

Menurut Stafford (dalam Saifuddin, 2013) endorser adalah individu yang mendukung atau merekomendasikan produk, perilaku, layanan, dan merek tertentu kepada khalayak. Seorang endorser adalah sumber komunikasi pemasaran yang dapat mempengaruhi pembentukan dan perubahan sikap. Sumber yang digunakan akan lebih efektif jika pasar yang dituju memandang bahwa sumber memiliki kredibilitas, penggunaan selebriti sebagai endorser juga sangat efektif karean selebriti merupakan kelompok sibolik yang banyak dipuja, selain itu menjadi sponsor untuk acara-acara dapat pula meningkatkan pertumbuhan aktivitas pemasaran. Berdasarkan latar belakang yang telah diuraikan, penelitian ini bertujuan untuk mengetahui pengaruh vanity seeking, purchase experience, celebrity endorser pada minat beli ulang dengan sikap terhadap Laneige sebagai variabel mediasi

\section{KERANGKA TEORITIS}

\section{Perilaku konsumen}

Konsumen adalah orang atau kelompok yang harus dilayani. Begitu pentingnya peran konsumen, sering konsumen dianggap sebagai raja yang harus dilayani kebutuhan dan keinginannya. Setiap konsumen memiliki kebutuhan dan keinginan yang berbeda satu sama lain, hal ini menyebabkan para pemasar perlu mempelajari bagaimana perilaku konsumen agar bisa membuat berbagai keputusan pemasaran yang tepat.

Menurut Hawkins \& Mothersbaugh (2013), perilaku konsumen adalah studi tentang individu, kelompok, atau organisasi dan proses yang mereka lakukan untuk memilih, mengamankan, menggunakan, dan membuang produk, layanan, pengalaman, atau ide untuk memenuhi kebutuhan dan dampak yang dimiliki proses ini terhadap 
JEMAP: Jurnal Ekonomi, Manajemen, Akuntansi, dan Perpajakan ISSN: 2622-612X (Media Online) | Vol.3 | No.2 | Oktober 2020

konsumen dan masyarakat. Dalam model perilaku konsumen, digambarkan bahwa konsumen mendapat rangsangan pemasaran. Rangsangan pemasaran ini mempengaruhi kesadaran konsumen dan melalui serangkaian proses psikologis digabungkan dengan karakteristik tertentu konsumen akan menghasilkan poses keputusan pembelian. Motivasi, persepsi, pembelajaran dan memori adalah empat proses psikologis yang secara fundamental mempengaruhi reaksi konsumen terhadap berbagai rangsangan pemasaran (Kotler \& Keller, 2016).

\section{Vanity Seeking}

Menurut Durvasula et al. (dalam Chang, Lu, Su, Lin \& Chang, 2011), vanity adalah sifat manusia yang dapat dipengaruhi oleh tekanan sosial. Menurut Netemeyer, Burton \& Lichtenstein (1995), vanity adalah kepedulian dan pandangan positif seseorang terhadap penampilan fisik dan pencapaian pribadi. Dewasa ini banyak orang cenderung memuja penampilan fisik dan prestasi yang telah dicapai seseorang, hal ini mempengaruhi perilaku konsumen. Kecenderungan ini membuat pemasar produk kecantikan perlu membuat komunikasi pemasaran yang menunjukkan bahwa produk yang ditawarkan dapat memenuhi kebutuhan konsumen yang ingin meningkatkan penampilan dan status sosialnya.

\section{Purchase experience}

Pengalaman adalah hal yang sangat penting dalam perilaku konsumen. Pengalaman yang dimiliki oleh konsumen memiliki dampak penting pada apa yang dipelajari dan diingat oleh konsumen. Pengalaman yang positif dapat menyebabkan perilaku berulang, sedangkan pengalaman negatif dapat menyebabkan perilaku penghindaran (Arnold et al., 2002). Banyak peneliti menemukan bahwa pengalaman belanja konsumen sebelumnya memengaruhi perilaku belanja mereka di masa depan (Eastlick, Eastlick \& Lotz dalam Kaushik \& Singh, 2013). Pengalaman pembelian dapat memberikan gambaran kepada konsumen tentang suatu produk yang sudah dibeli sehingga saat akan membeli produk yang sama konsumen sudah memiliki referensi dan informasi. Selain itu pengalaman berbelanja konsumen turut pula mempengaruhi sikap mereka terhadap komunikasi pemasaran (Fransiska A. \& Dewi, 2018). 
JEMAP: Jurnal Ekonomi, Manajemen, Akuntansi, dan Perpajakan

ISSN: 2622-612X (Media Online) | Vol.3 | No.2 | Oktober 2020

Pengalaman berbelanja bisa diperoleh melalui online shop maupun berbelanja secara langsung di outlet.

\section{Celebrity Endorser}

Menurut Stafford (dalam Saifuddin, 2013) "An endorser is an individual who supports or recommends certain products, behaviors, services, and brands to audiences. Seseorang yang akan menjadi endorser harus memiliki kredibilitas. Menurut Stafford \& Day (dalam Saifuddin, 2013) kredibilitas adalah karakteristik positif yang dimiliki oleh endorser yang dapat digunakan untuk mempengaruhi orang lain untuk menerima argumen yang disampaikan endorser. Keahlian, dapat dipercaya dan, daya tarik fisik merupakan dimensi inti kredibilitas yang harus dimiliki oleh seseorang yang menjadi endorser (Dellink, 2017)

Selebriti adalah kelompok referensi simbolik karena mereka disukai, dikagumi, dan sering memiliki tingkat kredibilitas yang tinggi untuk mempengaruhi konsumen (Arnold et al., 2002). Kredibiltas celebrity yang tinggi membuat pemasar sering menggunakan celebrity sebagai endorser untuk mempersonifikasikan merek karena karakteristik dan makna selebriti dapat ditransfer ke merek (Hawkins \& Mothersbaugh, 2013), selain itu celebrity endorser diharapkan dapat menimbulkan reaksi positif bagi penonton atau pembaca terhadap asosiasi selebriti dengan produk (Arnold et al., 2002).

Dalam beberapa penelitian tentang keefektifan celebrity endorsment dalam kaitannya dengan konsep diri konsumen, menemukan bahwa kesesuaian antara citra diri konsumen dan gambar selebritas memainkan peran penting dalam proses celebrity endorsment. Mereka menyatakan bahwa ketika seorang konsumen menganggap celebrity endorsment memiliki citra yang dekat dengan citra dirinya yang ideal, konsumen cenderung menilai iklan sebagai sesuatu yang menguntungkan dan melaporkan niat pembelian yang lebih besar (Dellink, 2017). Konsumen membeli barang dan jasa tertentu tidak hanya untuk kebutuhan mereka, tetapi juga untuk makna yang terkait. Individu mengadopsi sikap dan perilaku dari celebrity karena mereka menawarkan berbagai makna kepribadian dan gaya hidup yang selaras dengan citra diri (ideal) mereka Van der Veen (dalam Dellink, 2017). 
JEMAP: Jurnal Ekonomi, Manajemen, Akuntansi, dan Perpajakan

ISSN: 2622-612X (Media Online) | Vol.3 | No.2 | Oktober 2020

165

Sikap

Peter \& Olson (1999) mendefinisikan sikap sebagai evaluasi keseluruhan seseorang. Sikap adalah ringkasan pikiran, perasaan, dan tindakan konsumen (Arnold et al., 2002). Sikap dipelajari dari pengalaman langsung dengan produk, mulut ke mulut, paparan dari media massa, dan berbagai sumber informasi lain yang diperoleh oleh konsumen. Sikap mencerminkan evaluasi yang baik dan tidak baik terhadap objek sikap sehingga motivasi konsumen dalam memilih membeli atau tidak membeli produk atau merek tertentu.

Menurut Ferrinadewi (2008), sikap merupakan kunci yang menghubungkan antara atribut-atribut, persepsi dengan intensi dan perilaku konsumen. Konsumen akan membeli produk yang menurut mereka baik atau menguntungkan, sehingga pemasar perlu memastikan bahwa konsumen terus mempertahankan sikap positif terhadap produk setelah pembelian, karena hal ini dapat menyebabkan konsumen akan terus membeli produk yang sama berulang kali (Schiffman \& Wisenblit, 2015). Sikap positif merupakan aset yang berharga bagi perusahaan karena sikap positif yang mendalam dapat membantu konsumen melupakan berbagai kesalahan yang dilakukan secara tidak sengaja oleh merek (Ferrinadewi, 2008). Pembentukan sikap konsumen seringkali menggambarkan hubungan antara kepercayaan, sikap dan perilaku. Sikap dan perilaku juga terkait dengan atribut produk. Menurut Peter \& Olson (1999), sikap terdiri dari dua jenis konsep, yaitu objek dan perilaku, konsumen dapat memiliki sikap terhadapat berbagai objek fisik dan sosial seperti produk, merek, model, orang (pramuniga), juga aspek pemasaran (diskon dan iklan). Konsumen dapat pula memiliki sikap terhadap perilaku atau aksi diri sendiri seperti perilaku di masa lalu dan perilaku dimasa depan. Peter \& Olson (1999), menyebutkan bahwa konsumen dapat memiliki sikap yang sangat berbeda terhadap variasi konsep umum yang sama karena beberapa konsep sikap didefinisikan sesuai dengan konteks perilaku dan situasional tertentu.

\section{Minat Beli ULang}

Menurut Hicks et al., (dalam Ghassani,2017) minat beli ulang merupakan suatu komitmen konsumen yang terbentuk setelah konsumen melakukan pembelian suatu 
JEMAP: Jurnal Ekonomi, Manajemen, Akuntansi, dan Perpajakan

ISSN: 2622-612X (Media Online) | Vol.3 | No.2 | Oktober 2020

produk atau jasa. Menurut Kurniawati (2009) minat beli ulang yang tinggi mencerminkan tingkat kepuasan yang tinggi dari konsumen ketika memutuskan untuk mengadopsi suatu produk. Keputusan untuk mengadopsi atau menolak suatu produk timbul setelah konsumen mencoba suatu produk tersebut dan kemudian timbul rasa suka atau tidak suka terhadap produk tersebut. Rasa suka terhadap produk timbul bila konsumen mempunyai persepsi bahwa produk yang mereka gunakan berkualitas baik dan dapat memenuhi atau bahkan melebihi keinginan dan harapan konsumen. Minat beli ulang juga muncul bersamaan dengan sikap positif konsumen terhadap suatu produk atau merek, secara aktif menyukai suatu produk atau merek, dan merekomendasikan suatu produk atau merek secara positif kepada orang lain berdasarkan pengalaman sebelumnya (Oktavia, 2016). Niat pembelian kembali adalah kekuatan yang berharga untuk meningkatkan laba perusahaan dan pertumbuhan berkelanjutan (Wangwiboolkij, 2012). Thurau \& Klee (dalam Wangwiboolkij, 2012), telah mengakui bahwa pengalaman konsumen yang baik mengarah pada konsumsi ulang di masa depan.

\section{HIPOTESIS PENELITIAN}

Menurut Netemeyer et al. (1995) vanity adalah kepedulian dan pandangan positif seseorang terhadap penampilan fisik dan pencapaian pribadi. Vanity seeking merupakan salah satu karakteristik konsumen yang dapat mempengaruhi sikap konsumen. Penelitian yang dilakukan oleh Fransiska A. \& Dewi (2018), menunjukkan vanity seeking berpengaruh positif terhadap minat beli dengan sikap terhadap video tutorial rias wajah dan citra merek sebagai variabel mediasi. Penelitian yang dilakukan oleh Oktavia (2016), menunjukkan bahwa vanity seeking berpengaruh positif pada minat beli ulang jasa klinik kecantikan. Hipotesis pertama yang diajukan adalah sebagai berikut:

H1 (a-d): vanity seeking berpengaruh positif terhadap minat beli ulang dengan sikap terhadap Laneige sebagai variabel mediasi 
JEMAP: Jurnal Ekonomi, Manajemen, Akuntansi, dan Perpajakan

ISSN: 2622-612X (Media Online) | Vol.3 | No.2 | Oktober 2020

Pengalaman pembelian diperoleh ketika seorang konsumen membeli produk. Pengalaman ini dapat berupa pengalaman yang menyenangkan contohnya ketika produk yang dibeli oleh konsumen sesuai dengan ekspektasi dan pengalaman yang kurang menyenangkan Ketika produk yang dibeli tidak sesuai dengan ekspektasi (Fransiska A. \& Dewi, 2018). Pengalaman yang positif dapat menyebabkan perilaku berulang, sedangkan pengalaman negatif dapat menyebabkan perilaku penghindaran (Arnold,, 2002). Penelitian yang dilakukan oleh Fransiska A. \& Dewi, (2018) menunjukkan bahwa purchase experience berpengaruh positif terhadap minat beli dengan sikap terhadap video tutorial makeup dan brand image sebagai variabel mediasi. Penelitian yang dilakukan oleh Kuniawati (2009) menunjukkan bahwa semakin tinggi sikap terhadap merek maka akan semakin membangun minat beli ulang konsumen. Hipotesis kedua yang diajukan adalah sebagai berikut:

\section{H2 (b-d): Purchase experience berpengaruh positif terhadap minat beli ulang dengan sikap terhadap Laneige sebagai variabel mediasi}

Endorser adalah individu yang mendukung atau merekomendasikan produk, perilaku, layanan, dan merek tertentu kepada audiens. Keahlian, dapat dipercaya, dan daya tarik fisik merupakan dimensi inti kredibilitas yang harus dimiliki oleh seseorang yang menjadi endorser (Dellink, 2017). Selebriti adalah kelompok yang sering digunakan oleh pemasar sebagai endorser. Selebriti merupakan kelompok referensi simbolik karena mereka disukai, dikagumi, dan sering memiliki tingkat kredibilitas yang tinggi untuk mempengaruhi konsumen. Celebrity endorser diharapkan dapat menimbulkan reaksi positif bagi penonton atau pembaca terhadap asosiasi selebriti dengan produk. (Arnold et al., 2002). Penelitian yang dilakukan oleh Ferle \& Choi (2016), menunjukkan bahwa selebriti ternyata sangat efektif dalam menciptakan respons yang lebih menguntungkan. Penelitian Saifuddin (2013) menunjukkan kombinasi antara kredibilitas endorser dan kredibilitas merek sangat berdampak pada perilaku konsumen, hal tersebut tidak bisa dipisahkan, model tersebut dikenal dengan istilah Dual Credibility Model (DCM). Kedua hal tersebut sangat penting dan memiliki pengaruh yang besar terhadap sikap dan minat beli konsumen. Hipotesis ketiga yang 
JEMAP: Jurnal Ekonomi, Manajemen, Akuntansi, dan Perpajakan ISSN: 2622-612X (Media Online) | Vol.3 | No.2 | Oktober 2020

diajukan adalah sebagai berikut:

H4 (c-d): Celebrity Endorser berpengaruh positif terhadap minat beli ulang dengan sikap terhadap Laneige sebagai variabel mediasi

Berdasarkan hipotesis-hipotesis tersebut maka kerangka konseptual penelitiannya adalah sebagai berikut

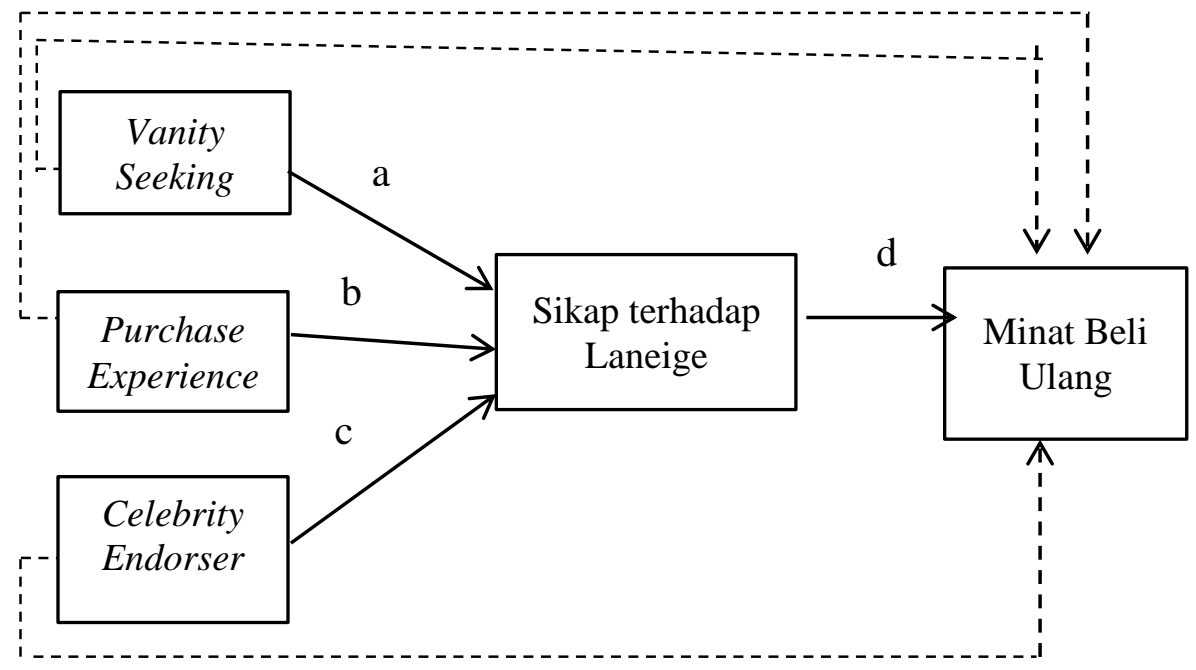

Bagan 1. Kerangka konseptual Penelitian

\section{METODE PENELITIAN}

Populasi dalam penelitian ini adalah populasi yang jumlahnya tidak diketahui (infinite population) yaitu seluruh konsumen Laneige yang berada di Yogyakarta. Dengan menggunakan perhitungan tertentu jumlah sampel pada penelitian ini sebesar 96 konsumen, yang pengambilan sampelnya menggunakan teknik convenience sampling. Menurut Sekaran (2006) convenience sampling mengacu pada pengumpulan informasi dari anggota populasi yang mampu menyediakan informasi dan mudah untuk diperoleh. Unit analisis pada penelitian ini adalah konsumen Laneige. Penelitian dilakukan pada bulan November 2019. Data yang digunakan adalah data primer dan data sekunder. Data diperoleh melalui kuesioner yang diberikan kepada konsumen 
JEMAP: Jurnal Ekonomi, Manajemen, Akuntansi, dan Perpajakan

ISSN: 2622-612X (Media Online) | Vol.3 | No.2 | Oktober 2020

pengguna Laneige. Pengukuran variabel dalam penelitian ini menggunakan skala likert. Menurut Sugiyono (2014) skala likert digunakan untuk mengukur sikap, pendapat, dan persepsi seseorang atau kelompok mengenai fenomena sosial (variabel penelitian). Jawaban setiap item instrumen yang digunakan diberi skala 1 (satu) sampai 5 (lima) yaitu sangat tidak setuju, tidak setuj, netral, setuju, dan sangat setuju.

Teknik analisis data dalam penelitian ini menggunakan SEM- Partial Least Squares (SEM-PLS). PLS dipilih untuk menganalisis data karena hubungan antar variabel yang cukup rumit dan harus diuji secara bersamaan, sehingga PLS dinilai lebih cocok digunakan. Menurut Sholihin \& Ratmono (2013) dasar pengambilan keputusan untuk menguji hipotesis mediasi adalah sebagai berikut: (1). Jika koefisien atau jalur path coefficient antar variabel independen dan variabel dependen dari direct effect ke indirect effect tidak berubah dan tetap signifikan, maka $\mathrm{H}_{0}$ diterima dan $\mathrm{H}_{\mathrm{a}}$ ditolak yang artinya hipotesis mediasi tidak didukung; (2) Jika koefisien atau jalur path coefficient antar variabel independen dan variabel dependen dari direct effect ke indirect effect nilainya turun dan tetap signifikan, maka $\mathrm{H}_{0}$ ditolak dan $\mathrm{H}_{\mathrm{a}}$ diterima dengan mediasi sebagai (partial mediation); (3). Jika koefisien atau jalur path coefficient antar variabel independen dan variabel dependen dari direct effect ke indirect effect nilainya turun dan menjadi tidak signifikan, maka $\mathrm{H}_{0}$ ditolak dan $\mathrm{H}_{\mathrm{a}}$ diterima dengan mediasi penuh (full mediation).

\section{HASIL PENELITIAN DAN PEMBAHASAN}

\section{Uji Validitas dan Reliabilitas}

Untuk mengetahui apakah instrumen penelitian (kuesioner) yang digunakan telah memenuhi syarat sebagai alat pengukur yang baik, dilakukan uji validitas konstruk dan uji reliabilitas. Uji validitas konstruk terdiri dari dua uji, yaitu uji validitas konvergen dan uji validitas diskriminan. Pada uji validitas konvergen suatu butir instrumen disebut valid bila nilai loading factor di atas 0,50, dengan nilai AVE harus di atas 0,50 (Wiyono, 2011). Sedangkan Menurut Chin, Gopal, \& Salinsbury (dalam Abdillah \& Jogiyanto 2015), suatu model memiliki validitas diskriminan yang cukup 
JEMAP: Jurnal Ekonomi, Manajemen, Akuntansi, dan Perpajakan

baik jika akar AVE untuk setiap konstruk lebih besar daripada korelasi antara konstruk lainnya. Berikut adalah hasil uji validitas yang dimaksud.

Tabel 1

Nilai Loading Factor

\begin{tabular}{cccc}
\multicolumn{4}{c}{ Nilai Loading Factor } \\
\hline No & $\begin{array}{c}\text { Item } \\
\text { Pernyataan }\end{array}$ & $\begin{array}{c}\text { Nilai } \\
\text { Loading Factor }\end{array}$ & Status \\
\hline 1 & X1.1 & 0,875 & Valid \\
2 & X1.2 & 0,875 & Valid \\
3 & X2.1 & 0,732 & Valid \\
4 & X2.2 & 0,774 & Valid \\
5 & X2.3 & 0,811 & Valid \\
6 & X2.4 & 0,586 & Valid \\
7 & X2.5 & 0,609 & Valid \\
8 & X3.1 & 0,763 & Valid \\
9 & X3.2 & 0,759 & Valid \\
10 & X3.3 & 0,704 & Valid \\
11 & X3.4 & 0,855 & Valid \\
12 & X3.5 & 0,620 & Valid \\
13 & Z.1 & 0,829 & Valid \\
14 & Z.2 & 0,757 & Valid \\
15 & Z.3 & 0,883 & Valid \\
16 & Y.1 & 0,884 & Valid \\
17 & Y.2 & 0,851 & Valid \\
18 & Y.3 & 0,774 & Valid \\
19 & Y.4 & 0,789 & Valid \\
\hline Sumber: Data diolah dengan WarpPLS 6.0 &
\end{tabular}

Berdasarkan Tabel 1 item pernyataan untuk semua variabel dinyatakan valid karena memiliki nilai loading factor $>0,60$

Tabel 2

Nilai Akar AVE dan Korelasi Variabel Laten

\begin{tabular}{cccccc}
\multicolumn{7}{c}{ Nilai Akar AVE dan Korelasi Variabel Laten } \\
\hline VS & VS & PE & CE & S & NBU \\
PE & 0.875 & 0.362 & 0.430 & 0.435 & 0.412 \\
CE & 0.430 & 0.708 & 0.443 & 0.679 & 0.623 \\
S & 0.435 & 0.443 & 0.744 & 0.567 & 0.524 \\
MBU & 0.412 & 0.623 & 0.567 & 0.825 & 0.782 \\
& & & 0.524 & 0.782 & 0.825 \\
\hline
\end{tabular}

Sumber: Data diolah dengan WarpPLS 6.0

Berdasarkan Tabel 2 semua variabel dinyatakan valid karena nilai akar AVE $>$ korelasi variabel laten. Setelah dilakukan uji validitas konvergen dan validitas deskriminan, selanjutnya dilakukan uji reliabilitas. Adapun hasil uji reliabilitas seperti pada Tabel 3 berikut. 
JEMAP: Jurnal Ekonomi, Manajemen, Akuntansi, dan Perpajakan

Tabel 3

Cronchbach's Alpha dan Composite Reliability

\begin{tabular}{clccc}
\hline \multirow{2}{*}{ No } & \multicolumn{1}{c}{ Variabel } & $\begin{array}{c}\text { Cronchbach's } \\
\text { Alpha }\end{array}$ & $\begin{array}{c}\text { Composite } \\
\text { Reliablity }\end{array}$ & Status \\
\hline 1 & Vanity Seeking & 0.693 & 0.867 & Reliabel \\
2 & Purchase experience & 0.746 & 0.832 & Reliabel \\
3 & Celebrity endorser & 0.795 & 0.860 & Reliabel \\
4 & Sikap & 0.763 & 0.864 & Reliabel \\
5 & Minat beli ulang & 0.843 & 0.895 & Reliabel \\
\hline \multicolumn{4}{c}{ Sumber: Data diolah dengan WarpPLS 6.0 }
\end{tabular}

Berdasarkan tabel 3 dapat diketahui bahwa semua variable dapat dinyatakan reliabel karena semua nilai composite reliability >0,70 dan cronchbach's alpha >0,60.

\section{Uji Hipotesis}

Pengujian hipotesis efek mediasi dilakukan dua langkah yaitu direct effect dan indirect effect (Sholihin \&ratmono,2013). Estimasi direct effect dilakukan antara variabel independen dan dependen. Dalam penelitian ini direct effect dilakukan untuk melihat pengaruh langsung vanity seeking, purchase experience, dan celebrity endorser terhadap minat beli ulang. Estimasi indirect effect dilakukan secara simultan dengan menambahkan variabel mediasi diantara variabel independen dan dependen. Dalam penelitian ini estimasi indirect effect dilakukan untuk mengetahui pengaruh vanity seeking, purchase experience, dan celebrity endorser terhadap minat beli ulang setelah dimediasi oleh sikap. Berikut ini dikemukakan bagan yang menjelaskan direct effect variabel independen (vanity seeking, purchase experience, dan celebrity endorser) terhadap variabel dependen (minat beli ulang)

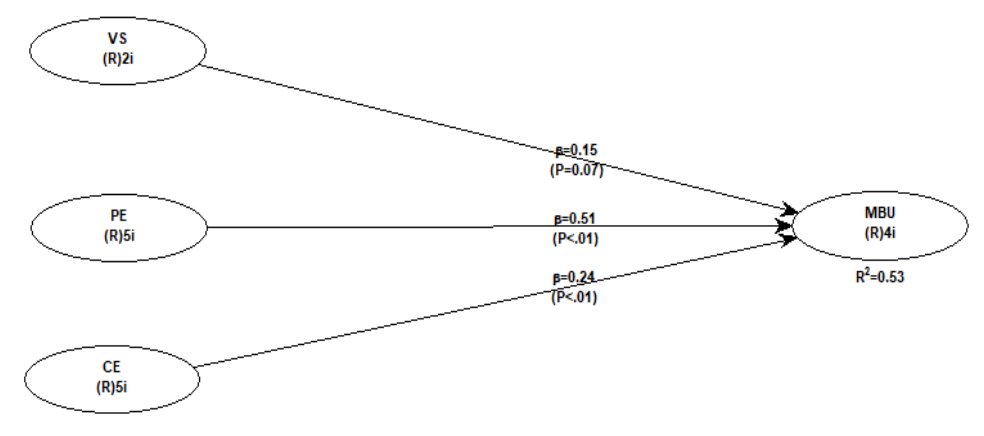

Bagan 1

Model Direct Effect dengan WarpPLS 6.0 
JEMAP: Jurnal Ekonomi, Manajemen, Akuntansi, dan Perpajakan ISSN: 2622-612X (Media Online) | Vol.3 | No.2 | Oktober 2020

Apabila dikemukakan dalam bentuk tabel, nilai path coeffiiciant dan p-value hasil estimasi direct effect tersebut nampak pada Tabel 5 berikut.

Tabel 5

Hasil Estimasi Direct Effect

\begin{tabular}{clccl}
\hline No & Variabel & $\begin{array}{c}\text { Path } \\
\text { Coefficient }\end{array}$ & P Value & \multicolumn{1}{c}{ Status } \\
\hline 1 & VS $\rightarrow$ MBU & 0.148 & 0.067 & Tidak signifikan \\
2 & $\mathrm{PE} \rightarrow \mathrm{MBU}$ & 0.512 & $<0.001$ & Signifikan \\
3 & $\mathrm{CE} \rightarrow \mathrm{MBU}$ & 0.243 & 0.006 & Signifikan \\
\hline
\end{tabular}

Sumber: Data diolah dengan WarpPLS 6.0

Setelah dilakukan perhitungan direct effect variabel independen terhadap variabel dependen, langkah berikutnya dilakukan pengujian hipotesis direct effect variabel independent (vanity seeking, purchase experience, dan celebrity endorser) terhadap variabel dependen (minat beli ulang). Dengan sikap terhadap Laneige sebagai variabel mediasi. Pengujian hipotesis tersebut nampak pada bagan 2 berikut.

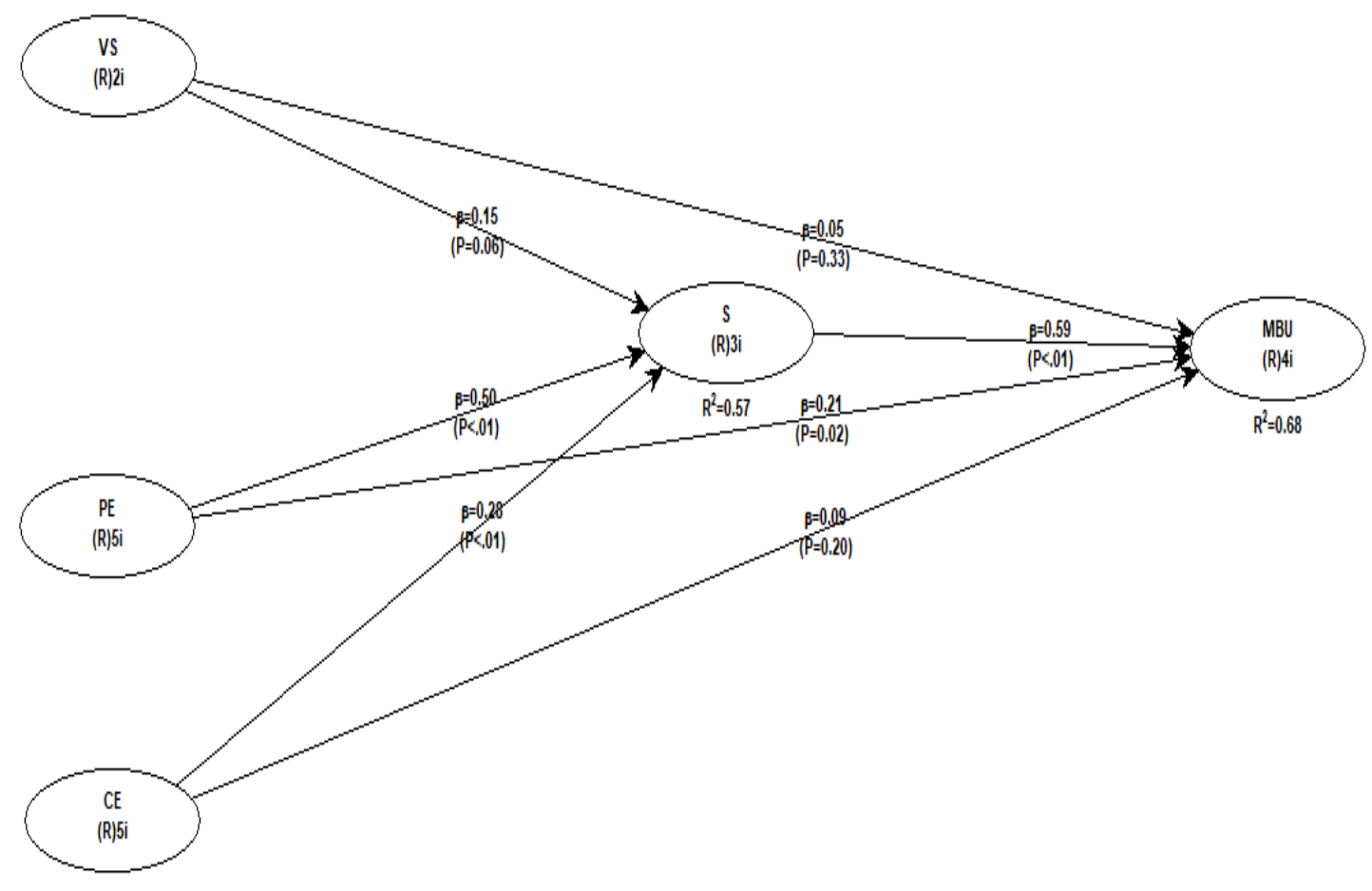

Bagan 2

Pengujian Model Inderect Effect dengan WarpPLS 6.0 
JEMAP: Jurnal Ekonomi, Manajemen, Akuntansi, dan Perpajakan

ISSN: 2622-612X (Media Online) | Vol.3 | No.2 | Oktober 2020

Apabila dikemukakan dalam tabel, nilai path coeffiiciant dan p-value hasil estimasi indiect effect tersebut nampak pada Tabel 6 berikut.

Tabel 6

Hasil Estimasi Indirect Effect

\begin{tabular}{ccccl}
\hline NO & Variabel & $\begin{array}{c}\text { Path } \\
\text { Coefficient }\end{array}$ & P Value & \multicolumn{1}{c}{ Status } \\
\hline 1 & $\mathrm{VS} \rightarrow \mathrm{S}$ & 0.152 & 0.062 & Tidak signifikan \\
2 & $\mathrm{PE} \rightarrow \mathrm{S}$ & 0.502 & $<0.001$ & Signifikan \\
3 & $\mathrm{CE} \rightarrow \mathrm{S}$ & 0.281 & 0.002 & Signifikan \\
4 & $\mathrm{VS} \rightarrow \mathrm{MBU}$ & 0.045 & 0.327 & Tidak signifikan \\
5 & $\mathrm{PE} \rightarrow \mathrm{MBU}$ & 0.209 & 0.016 & Signifikan \\
6 & $\mathrm{CE} \rightarrow \mathrm{MBU}$ & 0.086 & 0.196 & Tidak signifikan \\
7 & $\mathrm{~S} \rightarrow \mathrm{MBU}$ & 0.594 & $<0.001$ & Signifikan \\
\hline
\end{tabular}

Sumber: Data diolah dengan WarpPLS 6.0

\section{Pengujian hipotesis pengaruh vanity seeking terhadap minat beli ulang dengan sikap terhadap Laneige sebagai variabel mediasi.}

Hasil penelitian yang telah dilakukan menunjukkan bahwa vanity seeking tidak berpengaruh positif terhadap minat beli ulang dengan dimediasi oleh sikap terhadap Laneige. Hal ini terlihat dari dari nilai path coefficient vanity seeking pada minat beli ulang sebelum dimediasi oleh sikap terhadap Laneige sebesar 0,148 dengan p.value 0,06 (tidak signifikan), dan nilai path coefficient vanity seeking pada minat beli ulang setelah dimediasi oleh sikap terhadap Laneige sebesar 0,045 dengan p.value sebesar 0,327 (tetap tidak signifikan).

Menurut Krech et al., (dalam Wangwibookij, 2012), sikap merupakan salah satu faktor yang akan mempengaruhi minat beli ulang seseorang. Selain itu penelitian yang dilakukan Fransiska A. \& a Dewi. (2018) menunjukkan bahwa vanity seeking behavior berpengaruh positif pada sikap terhadap video tutorial make up, sikap berpengaruh positif terhadap citra merek dan citra merek mempengaruhi minat beli dan Penelitian yang dilakukan oleh Oktavia (2016) menunjukkan bahwa vanity seeking berpengaruh positif terhadap minat beli ulang jasa klinik kecantikan. Hasil penelitian ini tidak sejalan dengan penelitian sebelumnya. Hal ini menunjukkan bahwa belum 
JEMAP: Jurnal Ekonomi, Manajemen, Akuntansi, dan Perpajakan

ISSN: 2622-612X (Media Online) | Vol.3 | No.2 | Oktober 2020

tentu tingkat vanity seseorang yang tinggi akan membuatnya memilih merek tertentu hanya karena merek tersebut terkenal.

Menurut Hawkins \& Mothersbaugh (2010), konsumen sering memilih produk yang sesuai dengan kepribadiannya. Faktor kepribadian yang berbeda-beda yang membuat kosumen tidak memiliki sikap yang baik terhadap suatu produk atau merek tertentu selain itu kecocokan antara konsep diri konsumen turut serta mempengaruhi sikap konsumen terhadap Laneige, hal ini berdampak pada kurangnya minat konsumen untuk kembali membeli Laneige karena kurangnya kecocokan antara kepribadian dan konsep diri konsumen dengan Laneige. Selain itu adanya kemungkinan ketidak kecocokan produk dengan dengan kulit konsumen akan membuat konsumen berpindah menggunakan produk lain yang cocok dengan kulitnya dan mampu menunjang penampilannya sehingga konsumen tidak berminat untuk kembali membeli laneige.

\section{Pengujian hipotesis pengaruh purchase experience pada minat beli ulang dengan sikap terhadap Laneige sebagai variabel mediasi.}

Hasil penelitian yang telah dilakukan menunjukkan bahwa purchase experience berpengaruh positif pada minat beli ulang dengan dimediasi sebagian (partial mediation) oleh sikap terhadap Laneige. Hal ini dapat terlihat dari path coefficient pada direct effect sebesar 0,512 turun menjadi 0,209 pada indirect effect dan tetap signifikan setelah dimediasi oleh sikap terhadap Laneige. Hasil penelitian ini menunjukkan bahwa pengalaman berbelanja Laneige yang baik dapat mempengaruhi minat beli ulang konsumen akan Laneige dengan dimediasi oleh sikap.

Penemuan ini didukung oleh teori yang dikemukakan oleh Arnold, et al. (2002) yaitu pengalaman yang dimiliki konsumen memiliki dampak penting pada apa yang dipelajari dan diingat oleh konsumen. Pengalaman yang positif dapat menyebakan perilaku berulang dan pengalaman negatif menyebabkan perilaku penghindaran. Menurut Kaushik \& Singh (2013), banyak penelitian menemukan bahwa pengalaman belanja sebelumnya mempengaruhi perilaku belanja mereka di masa depan. Selain itu 
JEMAP: Jurnal Ekonomi, Manajemen, Akuntansi, dan Perpajakan

ISSN: 2622-612X (Media Online) | Vol.3 | No.2 | Oktober 2020

menurut Krech et al., (dalam Wangwibookij, 2012) sikap merupakan salah satu faktor yang akan mempengaruhi minat beli ulang seseorang. Konsumen akan memiliki sikap yang menguntungkan jika mereka merasakan bahwa produk yang ditawarkan mampu memenuhi keinginan dan kebutuhannya.

Menurut Fransiska A. \& Dewi (2018), sikap berkaitan dengan perilaku membeli, sikap terbentuk sebagai hasil dari pengalaman langsung mengenai produk, informasi secara lisan yang diperoleh dari orang lain atau terpapar oleh iklan di media masa, internet dan berbagai bentuk pemasaran langsung. Sikap dapat mendorong konsumen kearah perilaku tertentu atau menarik konsumen dari perilaku tertentu. Salah satu faktor yang mempengaruhi pembetukan sikap konsumen adalah faktor internal. Faktor internal berasal dari dalam diri seseorang yaitu bagaimana sesorang akan akan menanggapi objek yang ada disekitarnya. Objek yang akan disikapi adalah objek yang melekat pada sesorang atau individu. Hal ini berhubungan dengan informasi yang diperoleh dan pengalaman langsung dengan objek, dimana objek tersebut merupakan hal yang dibutuhkan, diinginkan atau disukai. Selain itu penelitian yang dilakukan oleh Kurniawati (2009) menunjukkan bahwa semakin tinggi sikap terhadap merek maka akan semakin membangun minat beli ulang. Hal ini menunjukkan bahwa sikap positif berdasarkan pengalaman yang positif dapat mempengaruhi minat beli ulang konsumen.

\section{Pengujian hipotesis pengaruh celebrity endorser pada minat beli ulang dengan sikap terhadap Laneige sebagai variabel mediasi.}

Hasil penelitian yang telah dilakukan menunjukkan bahwa celebrity endorser berpengaruh positif pada minat beli ulang dengan dimediasi penuh (full mediation) oleh sikap terhadap Laneige. Hal ini terlihat dari nilai path coefficient pada direct effect sebesar 0,243 turun menjadi 0,086 dan menjadi tidak signifikan setelah dimediasi oleh sikap terhadap Laneige. Temuan ini menunjukkan bahwa penggunaan celebrity endorser didalam komunikasi pemasaran Laneige sangat efektif, karena selebriti merupakan kelompok simbolik yang banyak dipuja, selain itu menjadi sponsor untuk 
JEMAP: Jurnal Ekonomi, Manajemen, Akuntansi, dan Perpajakan

ISSN: 2622-612X (Media Online) | Vol.3 | No.2 | Oktober 2020

acara-acara dapat pula meningkatkan pertumbuhan kegiatan pemasaran.

Temuan ini didukung oleh teori yang dikemukakan oleh Hawkins \& Mothersbaugh (2010), yang menyatakan bahwa selebriti adalah kelompok referensi simbolik karena mereka disukai, dikagumi, dan sering memiliki tingkat kredibilitas yang tinggi untuk mempengaruhi konsumen. Selain itu penelitian yang dilakukan oleh Dellink (2017), menunjukkan sikap terhadap iklan secara signifikan memengaruhi niat untuk mengunjungi tujuan liburan tertentu. Penelitian yang dilakukan oleh Ferle \& Choi (2016) menunjukkan bahwa selebriti ternyata sangat efektif dalam menciptakan respons yang lebih menguntungkan.

Menurut Hawkinss \& Mothersbough (2013), karakteristik komunikasi dapat mempengaruhi pembentukan sikap salah satunya adalah karakteristik sumber. Karakteristik sumber mewakili siapa yang menyampaikan pesan. Sumber yang dimaksud adalah artis, konsumen khas, endorser dan lain-lain. Sumber sangat penting karena konsumen akan merespon secara berbeda terhadap pesan yang sama yang disampaikan oleh sumber yang berbeda. Sumber yang digunakan akan lebih efektif jika pasar yang dituju memandang bahwa sumber memiliki kredibilitas.

Krech et al., (dalam Wangwibookij, 2012) menyatakan bahwa sikap merupakan salah satu faktor yang akan mempengaruhi minat beli ulang seseorang. Penelitian lain yang dilakukan oleh Kurniawati (2009) menunjukkan bahwa semakin tinggi sikap terhadap merek maka akan semakin membangun minat beli ulang konsumen. Dapat ditarik kesimpulan bahwa celebrity endorser memainkan peran yang sangat penting dalam pembentukan sikap positif konsumen terhadap suatu merek karena sikap positif konsumen dapat menjadi faktor yang mendorong minat konsumen untuk membeli kembali Laneige

\section{Pemaknaan Nilai $\mathbf{R}^{2}$}

\begin{tabular}{llc}
\multicolumn{2}{c}{$\begin{array}{c}\text { Tabel 4 } \\
\mathbf{R}^{\mathbf{2}}\end{array}$} \\
\hline No & Variabel & $\mathrm{R}^{2}$ \\
\hline 1 & Sikap & 0.554 \\
2 & Minat Beli Ulang & 0.668 \\
\hline
\end{tabular}

Sumber: Data diolah dengan WarpPLS 6.0 
JEMAP: Jurnal Ekonomi, Manajemen, Akuntansi, dan Perpajakan

Dari tabel 4, dapat diketahui bahwa nilai $\mathrm{R}^{2}$ variabel sikap sebesar 0,554, hal ini menunjukkan bahwa sikap dapat dijelaskan sebesar 55,4\% oleh vanity seeking, purchase experience, dan celebrity endorser sedangkan sisanya sebesar 44,6\% dijelaskan oleh variabel lain diluar penelitian ini. Nilai $\mathrm{R}^{2}$ variabel minat beli ulang sebesar 0,668, hal ini menunjukkan bahwa minat beli ulang dapat dijelaskan sebesar $66,8 \%$ oleh variabel vanity seeking, purchase experience, dan celebrity endorser, sedangkan sisanya 33,2\% dipengaruhi oleh variabel lain di luar penelitian ini.

\section{KESIMPULAN DAN SARAN}

\section{Kesimpulan}

Berdasarkan hasil penelitian yang telah diuraikan maka ada beberapa hal yang dapat disimpulkan yaitu sebagai berikut: Pertama, Vanity seeking tidak berpengaruh positif pada minat beli ulang dengan sikap terhadap Laneige sebagai variabel mediasi. Kedua, Purchase experience berpengaruh positif pada minat beli ulang dengan dimediasi sebagian (partial mediation) oleh sikap terhadap Laneige. Ketiga, celebrity endorser berpengaruh positif pada minat beli ulang dengan dimediasi penuh (full mediation) oleh sikap terhadap Laneige

\section{Saran}

Perusahaan sangat perlu untuk memberikan pengalaman berbelanja yang berbeda bagi konsumennya. Hal ini perlu dilakukan karena pengalaman konsumen berdampak pada apa yang dipelajari dan dingat oleh konsumen. Untuk menciptakan pengalaman berbelanja yang baik dapat dilakukan melalui pelayanan yang baik, packing yang baik dan sesuai standar yang berlaku sehingga barang sampai ke tangan konsumen dalam keadaan baik, membuat outlet serta online shop semenarik mungkin.

Sebaiknya perusahaan menyediakan layananan kosultasi gratis kepada konsumen agar mereka agar mereka bisa memilih produk Laneige yang sesuai dengan kebutuhan dan kepribadian konsumen. Selanjutnya Laneige sebaiknya tetap mempertahankan menggunakan aktris, aktor, boy dan girl band yang popular dalam 
JEMAP: Jurnal Ekonomi, Manajemen, Akuntansi, dan Perpajakan

membuat komunikasi pemasarannya. Selain itu pihak Laneige mungkin bisa mengadakan jumpa fans untuk endorser yang mereka gunakan dengan tujuan untuk menarik minat kosumen untuk datang ke boutique store Laneige dan membeli produk kecantikan yang ditawarkan oleh Laneige.

Diharapkan adanya penelitian di wilayah-wilayah lain terutama dikota-kota besar yang memiliki lebih banyak outlet Laneige. Selanjutnya dapat menguji faktor lain diluar variabel vanity seeking, purchase experience, dan celebrity endorser. Peneliti selanjutnya dapat menguji ulang model ini di wilayah yang berbeda atau menambah dan mengganti variabel independen penelitian.

\section{DAFTAR PUSTAKA}

Abdillah, Willy \& Hartono, Jogiyanto. 2015. Partial Least Square (PLS): Alternatif Structural Equation Modeling (SEM) dalam Penelitian Bisnis. Yogyakarta: Andi Offset

Ahmed, Naveed, Omer Farooq, Junaid Iqbal, Bahaudin Zakariya, \& Mohammad Ali. 2014 "The Relationship among Vanity Trait, Shopping Values \& Compulsive Buying: An Evidence from University Shoppers". European Journal of Business and Management. Vol.6, No.28,

Arnold, Erick, Linda Price, \& George Zinkhan, 2002. Consumers Behavior. New York: MCGraw-Hill

Chang, Wei-Lung, Long-Chuan Lu, Hung-Jen Su, Tai An Lin, \& Kuang-Yu Chang. 2011. "The Relationship Among Consumer Vanity Trait, Materialism And Fashion Anxiety". African Journal of Business Management. Vol.5 (9), pp. 3466-3471

Dellink, Zita. 2017. "The Differential Effects Of Celebrity And Expert Endorsements On The Intention To Visit A Holiday Destination," tesis. Tilburg School of Humanities Tilburg University, Tilburg

Ferle \& Choi. 2012. "The Importance of Perceived Endorser Credibility in South Korean Advertising". Journal of Current Issues \& Research in Advertising

Ferrinadewi, Erna. 2008. Merek \& Psikologi Konsumen. Yogyakarta: Graha Ilmu 
JEMAP: Jurnal Ekonomi, Manajemen, Akuntansi, dan Perpajakan

Fransiska A., Dela. \& Ike Janita Dewi. 2018. "Pengaruh Karakteristik Psikografis Konsumen, Sikap terhadap Video Tutorial Make-Up, dan Citra Merk pada Minat Beli". Journal of Research in Business and Economic. Vol. 01, No. 01

Ghassani, Mahyarani Tiara. 2017. "Pengaruh Kualitas Produk terhadap Minat Beli Ulang Bandeng Juwana Vaccum melalui Kepuasan Konsumen Sebagai Variabel Intervening (Studi Kasus Pada PT. Bandeng Juwana Erlina Semarang)". Diponegoro Journal Of Social And Political Science. Hal 1-8

Hawkins \& Mothersbaugh. 2013 Consumer Behavior Building Marketing Strategy. Twelfth Ed. International Edition. New York: MCGraw-Hill

Kaushik \& Singh. 2013 “A study of Relationship Between Consumers' Online Shopping And/Or Purchasing Experience And Their Intentions To Purchase From Their Favorite Products/Items Websites". Conference Paper

Kotler \& Keller. 2016. Marketing Manajemen. 15e Global Edition, New Jersey: Pearson Education Limited

Kurniawati, Dyah. 2009. "Studi Tentang Sikap Terhadap Merek Dan Implikasinya Pada Minat Beli Ulang (Kasus Pada Produk Mi Instan Indomie Di Kota Semarang)". Tesis. Universitas Diponegoro

Netemeyer, Richard G, Scot Burton \& Donald R. Lichtenstein. 1995. "Trait Aspects of Vanity: Measurement and Relevance to Consumer Behavior," Journal of Consumer Research.Vol. 21, No. 4, pp. 612-626

Oktavia, Liendah F. 2016. "Pengaruh Brand Image, vanity Seeking, Materialism, dan kelompok acuan terhadap Minat Beli Ulang Jasa Kecantikan” Tesis. Fakultas Ekonomi Umiversitas Sanata Dharma

Peter, J Paul \& Jerry C Olson. 1999. Consumer Behavior and Marketig strategy. Fith Ed. Unnited States of America: MCGraw-Hill

Saifuddin, Muchammad. 2013. "Pengaruh Jenis Endorser Dan Brand Name Terhadap Sikap Atas Iklan, Sikap Atas Merk Dan Niat Pembelian Pada Produk High Dan Low Involvement," Jurnal Ekonomi dan Bisnis, Tahun XXIII, No. 3

Schiffman, Leon G. \& Joseph L. Wisenblit. 2015. Consumer Behavior. Eleventh Edition England: : Pearson Education Limited 
JEMAP: Jurnal Ekonomi, Manajemen, Akuntansi, dan Perpajakan

ISSN: 2622-612X (Media Online) | Vol.3 | No.2 | Oktober 2020

Sekaran, Uma. 2006. Research Methods for Business. Four ED Jakarta: Salemba Empat

Sholihin, Mahfud \& Dwi Ratmono. 2013. Analisis SEM-PLS dengan Warp PLS 3.0. Yogyakarta: Andi OffsetSumarwan

Sugiyono. 2014. Metode Penelitian Manajemen. Bandung: alfabeta

Wangwiboolkij, Rossarin. 2012. "Factors Influencing Repurchase Intention Of Thai Female Customers Toward Korean Cosmetics In Bangkok". UU-GSB eJuornal. Vol.5. No.1

Wiyono. Genro, 2011. Merancang Penelitian dengan Alat Analisis SPSS 17.0 \& Smart PLS 2.0. Yogyakarta: UPP STIM YKPN

https://marketeers.com/ini enam merek skincare favorit perempuan indonesia

https://marketeers.com/indonesia-jadi-pasar-terbesar-produk-skin-care dunia

https://www.cnnindonesia.com/hiburan/20190110173339-241-359969/penggemar-

hallyu-di-dunia-hampir-tembus-90-juta-orang

https://www.laneige.com/id/id/index.html 